\title{
Aplikasi Teknologi Near Infrared Reflectance Spectroscopy (NIRS) Untuk Membedakan Beras Apek dan Tidak Apek Menggunakan Metode Principal Component Analysis (PCA)
}

(Technology Application Near Infrared Reflectance Spectroscopy (NIRS) To Distinguish The Rice Is Stale And Not Stale Using The Principal Component Analysis Method (PCA))

\author{
Herlina $^{1}$, Susi Chairani ${ }^{1}$, Zulfahrizal ${ }^{{ }^{*}}$ \\ Program Studi Teknik Pertanian Fakultas Pertanian Universitas Syiah Kuala \\ *Corresponding author:zulfahrizal@unsyiah.ac.id
}

\begin{abstract}
Abstrak. Beras merupakan salah satu tanaman pangan utama hampir dari setengah populasi dunia. Beras sebagai menu pokok ini memiliki kandungan pati yang cukup besar. Selain itu, dalam beras juga mengandung vitamin, protein, mineral, dan air. Pendistribusian beras terkadang membuat beras rusak yang disebabkan oleh beberapa faktor, seperti penyimpanan yang terlalu lama, dan suhu tempat penyimpanan beras. Beras yang terendam air juga bisa menyebabkan beras itu rusak, seperti beras yang ada dalam gudang yang terkena air hujan yang dapat menyebabkan beras tersebut bau apek. Tujuan dari penelitian ini adalah membangun model pendugaan mutu beras berdasarkan sifat apek beras menggunakan metode Principal Component Analysis (PCA) dengan pretreatment De-Trending (DT). Penelitian ini menggunakan alat FT-IR IPTEK T-1516. Bahan yang digunakan adalah beras varietas Ciherang $20 \mathrm{~g}$ per sampel dengan total jumlah sebanyak 56 sampel. Untuk memperoleh beras apek dilakukan perendaman selama 2 jam dengan penyimpanan 2 hari, 4 hari dan 6 hari dan beras dikeringkan di bawah sinar matahari. Perlakuan terhadap bahan dibagi 2, pertama beras tanpa campuran dan kedua beras dengan campuran. Pencampuran beras bagus dengan beras apek dengan rasio $75 \%$ dan $25 \%$. Akuisisi spectrum beras dilakukan dalam bentuk tumpukan. Masing-masing sampel yang telah dimasukkan ke dalam botol plastik akan dilakukan pengambilan spektrum dengan cara diletakkan masing-masing sampel tersebut pada lubang sinar. Untuk mengekplorasi kemiripan spectrum antar sampel dan untuk mencari outlier data dengan menggunakan metode Hotteling $T^{2}$ ellipse. Hasil dari penelitian yang telah dilakukan diperoleh NIRS mampu menghasilkan klasifikasi beras bagus dan beras apek dengan tingkat keberhasilan di atas $80 \%$. Pretreatment DT mampu menghasilkan model klasifikasi beras sehingga mencapai keberhasilan 83,33\%.
\end{abstract}

Kata kunci : Beras, NIRS, PCA, Pretreatment.

Abstract. Rice is one of the main food crops of almost half the world's population. Rice as a staple menu has a considerable starch content. In addition, rice also contains vitamins, protein, minerals, and water. The distribution of rice sometimes destroys rice caused by several factors, such as too long storage, and the temperature where the rice is stored. Rice that is submerged in water can also cause the rice to be damaged, such as rice in a warehouse exposed to rain which can cause the rice to smell musty. The purpose of this study is to build a model for estimating the quality of rice based on the musty nature of rice using the Principal Component Analysis (PCA) method with pretreatment De-Trending (DT). This study used the FTIR tool of Science and Technology T-1516. The material used was rice of Ciherang variety of $20 \mathrm{~g}$ per sample with a total amount of 56 samples. To obtain musty rice, soaking is carried out for 2 hours with storage of 2 days, 4 days and 6 days and the rice is dried in the sun. Treatment of ingredients is divided into 2, first rice without mixture and both rice with mixture. Mixing good rice with musty rice with a ratio of $75 \%$ and 25\%. Acquisition of spectrum of rice is done in the form of piles. Each sample that has been inserted into a plastic bottle will be taken spectrum by placing each of these samples in a ray hole. To explore the similarity spectrum between samples and to find outliers of data using the T2 ellipse Hotteling method. The results of the research that has been done obtained by NIRS are able to produce a classification of good rice and musty rice with a success rate above $80 \%$. DT pretreatment was able to produce a rice classification model so that it achieved $83.33 \%$ success.

Keywords: Rice, NIRS, PCA, Pretreatment. 


\section{PENDAHULUAN}

Beras merupakan kebutuhan pokok masyarakat di Indonesia, sebenarnya tak hanya di Indonesia saja yang mengonsumsi beras atau nasi tetapi juga Negara lainnya. Jenis beras yang banyak dikonsumsi masyarakat adalah beras putih (milled rice). Beras mengandung vitamin, karbohidrat, lemak, protein, mineral, dan air, dan beras setelah dimasak memberikan volume yang cukup besar dengan kandungan kalori cukup tinggi, serta dapat memberikan berbagai zat gizi lain yang penting bagi tubuh, seperti protein dan beberapa jenis mineral. Menurut Setyono (2010), penyimpanan beras dalam waktu yang lama dengan kondisi yang kurang baik akan menyebabkan perubahan pada bau dan rasa beras. Kerusakan ini terutama disebabkan ketengikan yang terjadi pada kandungan lemak beras sehingga menimbulkan bau apek.

Pendekteksian ketengikan/keapekan beras secara cepat dan tepat dapat diwujudkan melalui pengembangan teknologi Near Infrared Reflectance Spectroscopy (NIRS). Menurut Cen dan He (2007) NIRS memiliki kemampuan potensial untuk menentukan beberapa parameter mutu secara bersamaan. Melalui pengembangan ilmu komputer dan chemometric, kemampuan aplikasi teknis NIRS menjadi lebih popular dan menarik banyak peneliti dalam bidang pangan. Komponen dengan presentas ekonsentrasi $0.1 \%$ dapat dideteksi dan dievaluasi menggunakan NIRS. Penelitian NIRS terkait beras yang pernah dilakukan diantaranya adalah Masyitah (2018) yang meneliti keaslian beras aceh dibanding beras ciherang dengan memperhatikan aspek kandungan zat yang terkandung dalam beras menggunakan NIRS. Selanjutnya Nurhasanah (2018) menggunakan NIRS untuk menduga kandungan kadar air beras. Oleh karena itu pada penelitian ini akan mencoba menggunakan NIRS untuk menduga mutu beras berdasarkan sifat apek beras.

\section{METODE PENELITIAN}

\section{Waktu dan Tempat}

Penelitian ini dilaksanakan pada bulan Mei sampai Desember 2018. Bertempat di Laboratorium Intrumentasi dan Elektronika, Jurusan Teknik Pertanian, Fakultas Pertanian, Universitas Syiah Kuala, Darussalam, Banda Aceh.

\section{Alat dan Bahan}

Alat yang digunakan pada penelitian ini adalah FT-IR IPTEK T-1516, botol plastik, timbangan, kamera dan Unscramble software ${ }^{\circledR} X$ version 10.5 , sedangkan bahan yang digunakan pada penelitian ini adalah beras varietas Ciherang sebanyak 20 gram per sampel. Setiap perlakuan terdiri dari 8 sampel dengan jumlah 7 perlakuan sehingga jumlah keseluruhan adalah sebanyak 56 sampel.

\section{Persiapan Bahan}

Pada penelitian ini beras disortasi yang berfungsi untuk memisahkan kotoran dan menir. Beras yang digunakan yaitu beras yang akan diapekan dan beras yang tidak apek. Dimana beras yang akan diapekkan yaitu dilakukan dengan cara perendaman selama waktu

dua jam, selanjutnya beras akan ditiriskan, dan disimpan selama 6 hari dengan selang waktu 2 hari, 4 hari, dan 6 hari, selanjutnya beras dikeringkan dibawah sinar matahari. Secara umum pada penelitian ini dilakukan dua macam perlakuan yang dirinci sebagai berikut : 
1. Perlakuan beras tanpa campuran terdiri dari :

a. Beras tanpa perendaman dan penyimpanan $\left(\mathrm{B}_{0}\right)$ yang terdiri dari 8 sampel.

b. Beras dengan perendaman dan penyimpanan dua hari $\left(\mathrm{BA}_{2}\right)$ yang terdiri dari 8 sampel.

c. Beras dengan perendaman dan penyimpanan empat hari $\left(\mathrm{BA}_{4}\right)$ yang terdiri dari 8 sampel.

d. Beras dengan perendaman dan penyimpanan enam hari $\left(\mathrm{BA}_{6}\right)$ yang terdiri dari 8 sampel.

2. Perlakuan beras dengan campuran terdiri dari :

a. Pencampuran beras $75 \% \mathrm{~B}_{0}$ dan $25 \% \mathrm{BA}_{2}$ yang terdiri dari 8 sampel.

b. Pencampuran beras $75 \% \mathrm{~B}_{0}$ dan $25 \% \mathrm{BA}_{4}$ yang terdiri dari 8 sampel.

c. Pencampuran beras $75 \% \mathrm{~B}_{0}$ dan $25 \% \mathrm{BA}_{6}$ yang terdiri dari 8 sampel.

\section{Pengaturan Alat NIRS}

Spectrum NIRS untuk beras didapatkan menggunakan FT-IR IPTEK T-1516. Menurut Zulfahrizal, et al (2017) instrument ini meradiasikan gelombangcahaya pada kisaran panjang gelombang antara 1000 sampai $2500 \mathrm{~nm}$ dan dikontrol oleh perangkat lunak Thermo Integration ${ }^{\circledR}$. Spectrum NIRS untuk sampel didapatkan menggunakan self developed FT-IR IPTEK T-1516, dengan konfigurasi alur kerja alat (workflow) dibangun dengan menggunakan perangkat lunak terintegrasi Thermo Integration ${ }^{\circledR}$. Workflow dibuat untuk mengatur alat agar berkerja untuk mengakuisisi spectrum diffuse reflectance sampel, lalu merata-ratakan hasilnya dan menyimpan hasil pemindaiannya dalam tiga bentuk file yaitu*.SPA, *.JDX dan *.CSV.

\section{Akuisisi Spektrum Absorban}

Akuisisi spectrum beras dilakukan dalam bentuk tumpukan. Masing-masing sampel yang telah dimasukkan ke dalam botol plastik akan dilakukan pengambilan spectrum dengan cara diletakkan masing-masing sampel tersebut pada lubang sinar. Data absorban diperoleh dengan cara mentransformasikan nilai reflektan/pantulan ke dalam bentuk $\log (1 / \mathrm{R})$.

\section{Pemeriksaan Data Outlier PCA + Hotteling $\mathbf{T}^{2}$ Elipse}

Principal Component Analysis (PCA) untuk mengekplorasi kemiripan spectrum antar sampel dan untuk mencari outliers data dengan menggunakan metode Hotteling $T^{2}$ ellipse. Data yang berada di luar elipskan dideteksi sebagai data outliers dan selanjutnya dibuang (Zulfahrizal et al, 2016).

\section{Pembuatan Model Klasifikasi}

Klasifikasi keapekan beras dilakukan berdasarkan tipikal spektrum yang didapatkan. Keseluruhan data dipakai sebagai dataset yang digunakan untuk membangun model klasifikasi mutu beras. Model prediksi dibangun dengan menggunakan metode PCA.

\section{HASIL DAN PEMBAHASAN}

\section{Karakteristik Beras Selama Penyimpanan}

Secara fisik beras B0 tampak bening dan tidak berbau. Setelah diberikan perlakuan perendaman dan penyimpnan terjadi perubahan fisik yaitu perbahan warna dan bau. Penyimpanan selama 2 hari $\left(\mathrm{BA}_{2}\right)$ menyebabkan warna beras berubah sedikit menjadi 
putih dan sedikit tercium bau apek. Penyimpanan selama 4 hari $\left(\mathrm{BA}_{4}\right)$ menyebabkan warna beras berubah sedikit kuning dan bau apek mulai menyengat. Penyimpanan selama 6 hari (BA6) menyebabkan warna mulai berubah sedikit coklat dan bau cukup menyengat.

Tabel 1. Perubahan Kandungan Karbohidrat,Lemak, dan Protein Selama Penyimpanan $\begin{array}{lllll}\text { Kandungan kimia beras } & \text { Beras } 0 \text { hari (\%) } & \text { Beras } 2 \text { hari (\%) } & \text { Beras } 4 \text { hari (\%) } & \text { Beras } 6 \text { hari (\%) }\end{array}$

\begin{tabular}{lcccc}
\hline Karbohidrat (Luff Schoorl) & 73,07 & 80,19 & 81,52 & 82,23 \\
Protein (Kjeldhal) & 7,78 & 7,07 & 5,54 & 4,71 \\
Lemak (Soxlet) & 1.25 & 0,45 & 0,36 & 0,50 \\
\hline
\end{tabular}

Sumber : Hasil Uji Laboratorium Kandungan Kimia Beras Tanpa Penyimpanan dan Penyimpanan (2018)

\section{Raw Spectrum Beras Tanpa Campuran}

Raw spectrum beras menunjukkan adanya puncak/lembah spectrum berdasarkan panjang gelombang ya ng menandakan keberadaan zat yang terkandung di dalamnya. Pada Gambar 1. Menampilkan satu spectrum beras yang mewakili dari setiap perlakuan beras. Secara umum terlihat bahwa raw spectrum beras tanpa campuran memiliki tipikal yang sama. Puncak gelombang penyerapan dapat terlihat sebanyak 6 puncak/lembah.

Puncak/lembah pertama mempunyai kisaran panjang gelombang 2301-2363 nm yang menunjukkan keberadaan lemak. Sesuai dengan pernyataan Cen and He (2007) kandungan lemak pada produk makanan mempunyai kisaran panjang gelombang 2280$2380 \mathrm{~nm}$ dan pernyataan Zulfahrizal et al (2013) dengan kisaran panjang gelomang 2320$2340 \mathrm{~nm}$ dan 2340-2360 nm yang terdapat kandungan lemak pada biji kakao.

Puncak/lembah gelombang kedua mempunyai kisaran panjang gelombang 2231$2300 \mathrm{~nm}$ yang menunjukkan keberadaan $\mathrm{CHO}$ yang diduga karbohidrat. Sesuai dengan pernyataan Firdaus dan Usman (2017) dengan kisaran panjang gelombang $2276 \mathrm{~nm}$ dan $2336 \mathrm{~nm}$ yang terdapat kandungan karbohidrat pada benih padi.

Puncak/lembah ketiga mempunyai kisaran panjang gelombang 2103-2241 nm menunjukkan $\mathrm{CONHR}$ dan $\mathrm{CH}_{3}$ yang diduga protein dan lemak. Sesuai dengan pernyataan Cen and He (2007) dengan kisaran panjang gelombang 2100-2200 nm terdapatkandungan protein danlemak pada produk makanan.

Puncak/lembah gelombang keempat mempunyai kisaran panjang gelombang 2079$2130 \mathrm{~nm}$ menunjukkan keberadaan CONH yang diduga protein. Sesuai dengan pernyataan Firdaus et al (2014) dengan kisaran panjang gelombang 2070-2085 nm yang terdapat kandungan protein pada benih padi.

Puncak/lembah gelombang kelima mempunyai panjang gelombang 1897-1984 nm yang menunjukkan keberdaan kadar air $\left(\mathrm{H}_{2} \mathrm{O}\right)$. Sesuai dengan pernyataan Osborn (1993) dengan panjang gelombang $1940 \mathrm{~nm}$ dan pernyataaan Cen and He (2007) dengan kisaran panjang gelombang 1850-1950 nm yang terdapat kandungan kadar air pada produk makanan dan pernyataan Zulfahrizal et al (2013) dengan kisaran panjang gelombang 1935$1955 \mathrm{~nm}$ yang terdapat kandungan kadar air pada kakao.

Puncak/lembah gelombang keenam mempunyai kisaran panjang gelombang 1404$1528 \mathrm{~nm}$ yang menunjukkan keberadaan $\mathrm{H}_{2} \mathrm{O}$ dan $\mathrm{CONH}_{2}$ yang diduga kadar air dan protein. Sesuai dengan pernyataan Cen and He (2007) dengan panjang gelombang 1480$1520 \mathrm{~nm}$ yang terdapat kandungan kadar air dan protein pada produk makanan. 


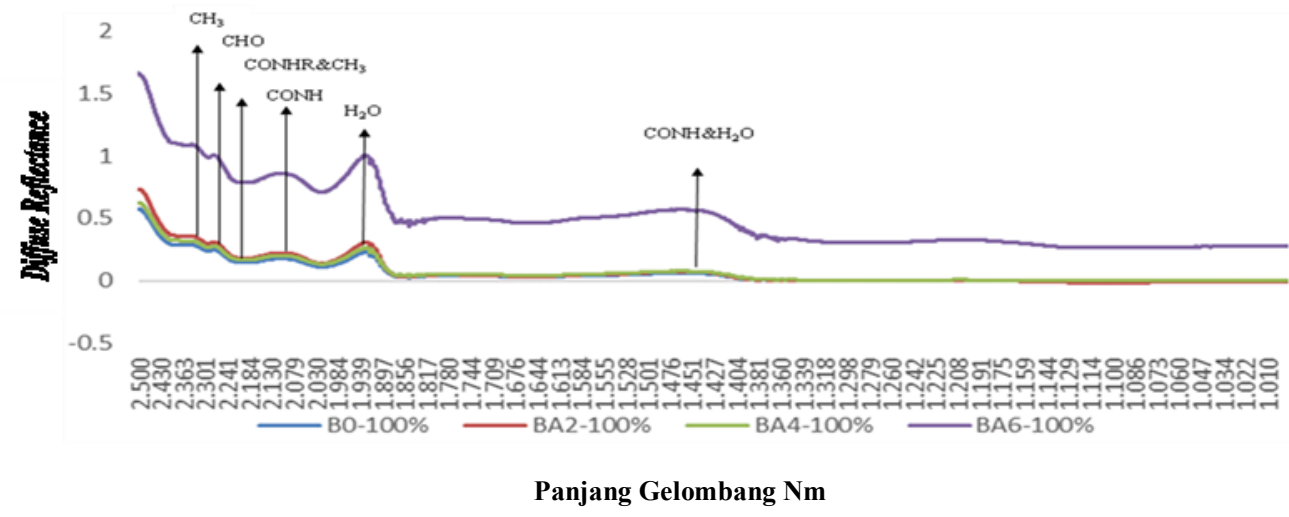

Gambar 1. Raw Spectrum Beras Tanpa Campuran

\section{Raw Spectrum Beras Campuran}

Spectrum antara $\mathrm{B}_{0}$ dengan spectrum campuran antara $\mathrm{B}_{0}+\mathrm{BA}_{2}(75 \%$ beras tanpa penyimpanan dan $25 \%$ beras penyimpanan 2 hari). Secara umum kedua spectrum mempunyai tipikal yang sama dan puncak yang sama. Hal ini dapat dipahami karena kandungan zat antara beras $\mathrm{B}_{0}$ dengan $\mathrm{BA}_{2}$ tidak begitu jauh berbeda. Sehingga kandungan zat beras campuran $\mathrm{B}_{0}+\mathrm{BA}_{2}$ relatif sama dengan beras $\mathrm{B}_{0}$.

Spectrum antara $\mathrm{B}_{0}$ dengan spectrum campuran antara $\mathrm{B}_{0}+\mathrm{BA}_{4}(75 \%$ beras tanpa penyimpan dan $25 \%$ beras penyimpanan 4 hari). Secara umum kedua spectrum mempunyai tipikal yang sama namun beberapa puncak gelombang terjadi pergeseran. Hal ini dapat dipahami karena kandungan zat antara beras $\mathrm{B}_{0}$ dengan $\mathrm{BA}_{4}$ mulai jauh berbeda terutama kandungan lemak dan protein. Sehingga kandungan zat beras campuran $\mathrm{B}_{0}+\mathrm{BA}_{4}$ cukup berbeda dengan beras $\mathrm{B}_{0}$.

Spectrum antara $\mathrm{B}_{0}$ dengan spectrum campuran antara $\mathrm{B}_{0}+\mathrm{BA}_{6}(75 \%$ beras tanpa penyimpan dan $25 \%$ beras penyimpanan 6 hari. Secara umum kedua spectrum mempunyai tipikal yang sama namun puncak-puncaknya sudah jauh berbeda. Hal ini dapat dipahami karena kandungan zat antara beras $\mathrm{B}_{0}$ dengan $\mathrm{BA}_{6}$ sudah sangat jauh berbeda terutama kandungan protein dan karbohidrat. Sehingga kandungan zat beras campuran $\mathrm{B}_{0}+\mathrm{BA}_{6}$ sudah jauh berbeda $\mathrm{B}_{0}$.

\section{Outlier Removal}

Setelah dilakukan akuisisi spectrum pada beras tanpa pencampuran maupun pencampuran langkah selanjutnya adalah mendeteksi keberadaan data pencilan dengan menggunakan metode PCA (Principal Component Analysis) yang dikombinasikan dengan Hotelling $T^{2}$ ellipse yang akan membuat data lebih sempurna. Setelah melakukan analisa data didapat dua data yang berada diluar garis ellipse. Data pertama disinyalir sebagai outlier sehingga dibuang (remove). Data kedua disinyalir sebagai data pengungkit sehingga tidak dibuang.

\section{Klasifikasi Beras Tanpa Campuran}

a. Klasifikasi Beras 0 Hari dan Beras 2 hari (100\%)

Klasifikasi metode ini dengan cara mengelompokkan data. Hasil analisis PCA tanpa pretreatment terlihat bahwa $\mathrm{B}_{0}$ (beras 0 hari 100\%) dan $\mathrm{BA}_{2}$ (beras 2 hari $100 \%$ ) 
yang mana keduanya tampak terpisah. Perlakuan tanpa pretreatment pada beras tanpa campuran menghasilkan total data $\left(\mathrm{PC}_{1}\right.$ dan $\left.\mathrm{PC}_{2}\right)$ adalah sebesar 99\%. Data ini terklasifikasi secara baik dengan persentase keberhasilan sebesar $81,25 \%$ yang mana beras 0 hari dan beras 2 hari masing-masing terklasifikasi $100 \%$ dan $62,5 \%$ yang mana data beras 2 hari terdapat 3 data gagal.

Klasifikasi dengan penambahan pretreatment DT pada beras 0 hari 100\%dan beras 2 hari 100\% menghasilkan total $\left(\mathrm{PC}_{1}\right.$ dan $\left.\mathrm{PC}_{2}\right)$ adalah sebesar 99\%. Data ini terklasifikasi secara baik dengan presentase keberhasilan $81,25 \%$. Beras 0 hari dan beras 2 hari terklasifikasi sebesar $100 \%$ dan $62,5 \%$ yang mana pada beras 2 hari terdapat 3 data gagal.

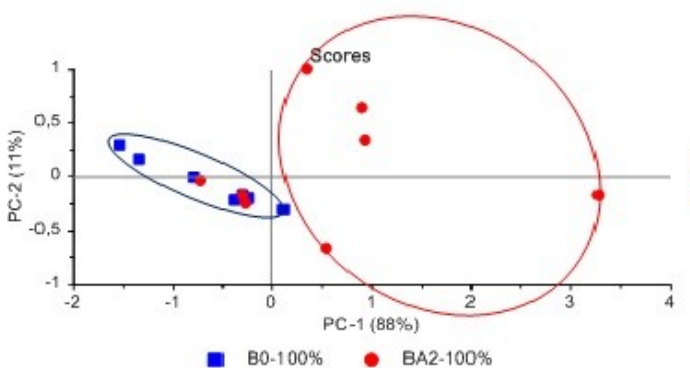

(a)

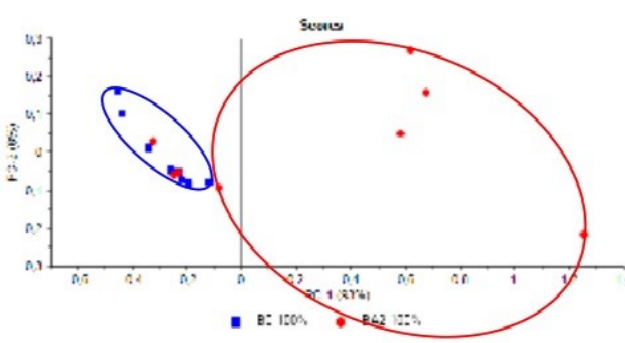

(b)

Gambar 2. (a) Klasifikasi Tanpa Pretreatment dan (b) Pretreatment DT Beras 0 Hari dan 2 Hari

b. Klasifikasi Beras 0 Hari dan Beras 4 Hari (100\%)

Klasifikasi beras 0 hari $100 \%$ dan beras 4 hari $100 \%$ tanpa pretreatment menggunakan metode PCA dapat membedakan dua jenis beras tersebut yang menghasilkan $\left(\mathrm{PC}_{1}\right.$ dan $\left.\mathrm{PC}_{2}\right)$ adalah sebesar $100 \%$. Data ini terklasifikasi sangat baik dengan presentase keberhasilan sebesar 87,5\%. Klasifikasi beras 0 hari dan beras 4 hari masing-masing terklasifikasi $87,5 \%$. Hal ini dikarenakan terdapat 1 data pada beras 0 hari dan 4 hari yang berada diluar posisinya.

Klasifikasi beras 0 hari $100 \%$ dan beras 4 hari 100\% menggunakan metode PCA dengan penambahan pretreatment DT menghasilkan total $\left(\mathrm{PC}_{1}\right.$ dan $\left.\mathrm{PC}_{2}\right)$ sebesar $93 \%$. Data ini terklasifikasi secara baik dengan persentase keberhasilan sebesar $81,25 \%$. Beras 0 hari dan beras 4 hari masing-masing terklasifikasi $87,5 \%$ dan $75 \%$. Hal ini dikarenakan terdatl data pada beras 0 hari yang berada diluar posisinya dan 2 data pada beras 4 hari yang diluar posisinya.

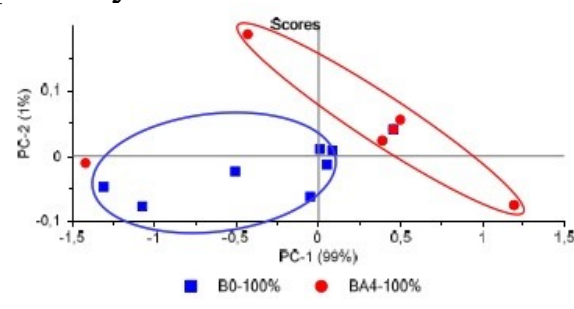

(a)

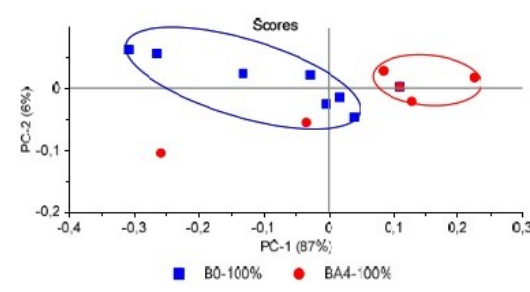

(b)

Gambar 3. (a) Klasifikasi Tanpa Pretreatment dan (b) Pretreatment DT Beras 0 hari dan 4 hari 
c. Klasifikasi Beras 0 Hari dan Beras 6 hari (100\%)

Klasifikasi beras 0 hari $100 \%$ dan beras 6 hari 100\% tanpa pretreatment menggunakan metode PCA berhasil dibedakan dengan mengasilkan total $\left(\mathrm{PC}_{1}\right.$ dan $\left.\mathrm{PC}_{2}\right)$ adalah sebesar 99\%. Data ini terklasifikasi baik dengan persentase keberhasilan sebesar $100 \%$. Klasifikasi beras 0 hari dan beras 6 hari masing-masing $100 \%$ dan $100 \%$.

Klasifikasi beras 0 hari $100 \%$ dan beras 6 hari $100 \%$ dengan penambahan pretreatment DT menggunakan berhasil dibedakan dengan mengasilkan total $\left(\mathrm{PC}_{1}\right.$ dan $\mathrm{PC}_{2}$ ) adalah sebesar 98\%. Data ini terklasifikasi cukup baik dengan persentase keberhasilan sebesar $100 \%$. Klasifikasi beras 0 hari dan beras 6 hari masing-masing $100 \%$.

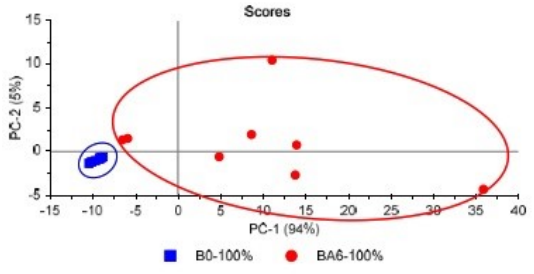

(a)

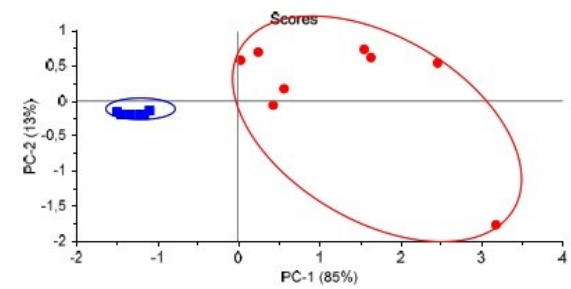

(b)

Gambar 4. (a) Klasifikasi Tanpa Pretreatment dan (b) Pretreatment DT Beras 0 hari dan 6 Hari

\section{Klasifikasi Beras Campuran}

a. Klasifikasi Beras Campuran 2 Hari (25\%) dan Beras 0 Hari (100\%)

Pada tahap ini pencampuran beras bagus dengan beras apek akan dikelompokkan menjadi dua kelompok yaitu beras 0 hari $100 \%$ dan beras 2 hari $25 \%$ (campuran beras bagus $75 \%$ dan beras apek $25 \%$ ) tanpa pretreatment menghasilkan total $\left(\mathrm{PC}_{1}\right.$ dan $\left.\mathrm{PC}_{2}\right)$ adalah sebesar 99\%. Data ini terklasifikasi cukup baik dengan persentase keberhasilan sebesar 75\%. Klasifikasi PCA tanpa pretreatment beras 0 hari sebesar $87,5 \%$ dan beras apek 2 hari sebesar $62,5 \%$ yang dikarenakan bahwa beras 0 hari terdapat 1 data yang keluar dari posisinya dan beras 2 hari terdapat 3 data yang berada diluar posisinya.

Klasifikasi metode PCA dengan penambahan pretreatment DT beras 0 hari $100 \%$ dengan beras 2 hari 25\% (campuran beras bagus 75\% dan beras apek 25\%) dengan penambahan pretreatment DT menghasilkan total $\left(\mathrm{PC}_{1}\right.$ dan $\left.\mathrm{PC}_{2}\right)$ adalah sebesar $92 \%$. Data ini terklasifikasi cukup baik dengan persentase keberhasilan sebesar 62,5\%. Klasifikasi PCA dengan pretreatment DT beras 0 hari sebesar $75 \%$ dan beras 2 apek hari sebesar $50 \%$. Hal ini dikarenakan pada beras 0 hari dari terdapat 2 data yang berada diluar posisinya dan beras 2 hari terdapat 4 data yang berada diluar posisinya.

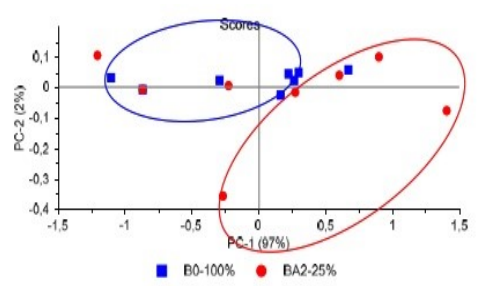

(a)

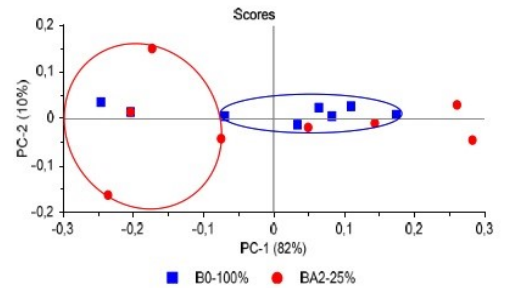

(b)

Gambar 5. (a) Klasifikasi Tanpa Pretreatment dan (b) Pretreatment DT Beras 0 Hari dan 2 hari 
b. Klasifikasi beras Campuran 4 Hari (25\%) dan Beras 0 Hari (100\%)

Klasifikasi metode PCA tanpa pretreatment pencampuran beras bagus dengan beras apek dikelompokkan menjadi dua kelompok yaitu beras 0 hari 100\%dan beras 4 hari $25 \%$ (campuran beras bagus $75 \%$ dan beras apek $25 \%$ ) menghasilkan total $\left(\mathrm{PC}_{1}\right.$ dan $\left.\mathrm{PC}_{2}\right)$ adalah sebesar $99 \%$. Data ini terklasifikasi secara baik dengan persentase keberhasilan sebesar $81,25 \%$. Klasifikasi PCA tanpa pretreatment beras 0 hari dan beras 4 hari masingmasing sebesar $87,5 \%$ dan $75 \%$. Hal ini dikarenakan beras 4 hari terdapat 2 data yang berada diluar posisinya.

Klasifikasi metode PCA dengan penambahan pretreatment DT beras 0 hari $100 \%$ dengan beras apek 4 hari 25\% (campuran beras bagus 75\% dan beras apek 25\%) dengan penambahan pretreatment DT menghasilkan total $\left(\mathrm{PC}_{1}\right.$ dan $\left.\mathrm{PC}_{2}\right)$ adalah sebesar $97 \%$. Data ini terklasifikasi cukup baik dengan persentase keberhasilan sebesar 87,5\%. Klasifikasi PCA dengan pretreatment DT beras 0 hari dan beras apek 4 hari masing-masing 87,5\%. Hal ini dikarenakan beras 0 dan 4 hari terdapat 1 data yang berada diluar posisinya.

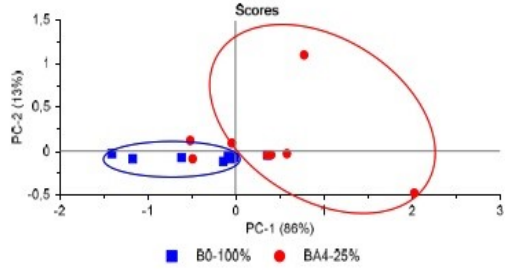

(a)

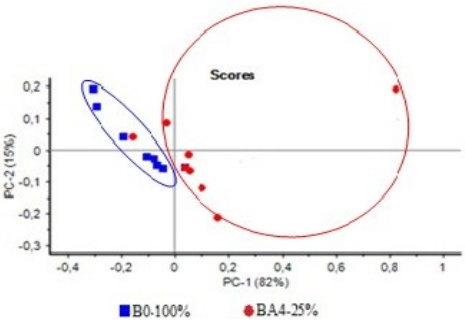

(b)

Gambar 6. (a) Klasifikasi Tanpa Pretreatment dan (b) Pretreatment DT Beras 0 Hari dan 4 hari

c. Klasifikasi Beras Campuran 6 Hari (25\%) dan Beras 0 Hari (100\%)

Klasifikasi metode PCA tanpa pretreatment pencampuran beras bagus dengan beras apek yang dikelompokkan menjadi dua kelompok yaitu beras 0 hari $100 \%$ dan beras 6 hari $25 \%$ (campuran beras bagus $75 \%$ dan beras apek $25 \%$ ) menghasilkan total $\left(\mathrm{PC}_{1}\right.$ dan $\mathrm{PC}_{2}$ ) adalah sebesar $100 \%$. Data ini terklasifikasi cukup baik dengan persentase keberhasilan sebesar $68,75 \%$. Klasifikasi PCA tanpa pretreatment beras 0 hari dan beras apek 6 hari masing-masing sebesar $100 \%$ dan 37,5\%. Hal ini dikarenakan beras 6hari terdapat 3 data yang berada diluar posisinya.

Klasifikasi metode PCA dengan penambahan pretreatment DT beras 0 hari $100 \%$ dengan beras 6 hari 25\% (campuran beras bagus 75\% dan beras apek 25\%) dengan penambahan pretreatment DT menghasilkan total $\left(\mathrm{PC}_{1}\right.$ dan $\left.\mathrm{PC}_{2}\right)$ adalah sebesar $99 \%$. Data ini terklasifikasi cukup baik dengan persentase keberhasilan sebesar 87,5\%. Klasifikasi PCA dengan pretreatment DT beras 0 hari dan beras apek 6 hari masing-masing $100 \%$ dan $75 \% \%$. Hal ini dikarenakan beras 6 hari terdapat 2 dat yang berada diluar posisinya.

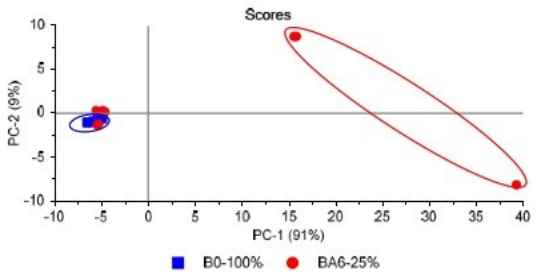

(a)

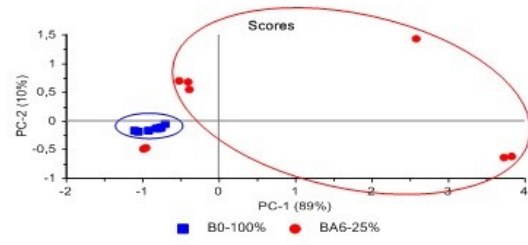

(b)

Gambar 7. (a) Klasifikasi Tanpa Pretreatment dan (b) Pretreatment DT Beras 0 Hari dan 6 hari 
Secara umum dapat disimpulkan bahwa PCA mampu mengklasifikasikan beras berdasarkan nilai keapekannya dimana semua model klasifikasi PCA menggunakan pretreatment dan tanpa pretreatment menghasilkan model $80 \%$. Pretreatment yang terbaik digunakan dalam penelitian berdasarkan sifat keapekan berasadalah peretreatment deterending (DT) dengan tabel keberhasilan klasifikasi 83,33\%.

Tabel. 2 Klasifikasi Beras Tanpa campuran dan Beras Campuran

\begin{tabular}{lccccccc}
\hline & \multicolumn{3}{c}{ BerasTanpa Campuran (100\%) } & \multicolumn{3}{c}{ Beras Campuran (25\%) } \\
\cline { 2 - 8 } & B0-BA2 & B0-BA4 & B0-BA6 & B0-BA2 & B0-BA4 & B0-BA6 & Total \\
\hline Non Pretreatment & 81,25 & 87,5 & 100 & 75 & 81,25 & 68,75 & 82,29 \\
DT & 81,25 & 81,25 & 100 & 62,5 & 87,5 & 87,5 & 83,33 \\
& & & & & & \\
\hline
\end{tabular}

\section{KESIMPULAN DAN SARAN}

\section{Kesimpulan}

Berdasarkan hasil penelitian yang telah dilakukan maka yang dapat disimpulkan sebagai berikut:

1. Spectrum NIRS beras menunjukkan keberadaan kandungan lemak pada panjang gelombang $2301 \mathrm{~nm}$ - $2363 \mathrm{~nm}$. Kandungan karbohidrat pada panjang gelombang $2231 \mathrm{~nm}-2300 \mathrm{~nm}$. Kandungan protein dan lemak pada panjang gelombang $2103 \mathrm{~nm}-2241 \mathrm{~nm}$. Kandungan protein pada panjang gelombang $2079 \mathrm{~nm}-2130 \mathrm{~nm}$.

2. Panjang gelombang $1897 \mathrm{~nm}$ - $1984 \mathrm{~nm}$ menunjukkan kandungan kadar air dan panjang gelombang $1404 \mathrm{~nm}-1528 \mathrm{~nm}$ menunjukkan kandungan kadar air dan protein.

3. NIRS mampu menghasilkan klasifikasi beras bagus dan beras apek dengan tingkat keberhasilan di atas $80 \%$.

4. Pretreatment de-trending mampu menghasilkan model klasifikasi beras sehingga mencapai keberhasilan 83,33\%

\section{Saran}

Berdasarkan hasil penelitian yang telah dilakukan, saran yang dapat dikemukakan untuk penelitian selanjutnya adalah :

1. Perlu penambahan sampel untuk variasi lebih pada kegiatan sehingga hasil pengklasifikasian lebih signifikan.

2. Beras yang digunakan dapat menggunakan beras yang terdapat pada Bulog. 


\section{DAFTAR PUSTAKA}

Cen, H dan Y. He. 2007. Theory and application of near infrared reflectance spectroscopy in determination of food quality. J. Trends in Food Sci \& Technol.18:72-83.

Firdaus, J. R. Hasbullah, U. Ahmad, dan M. R. Suhartanto. 2014. Deteksi cepat viabilitas benih padi menggunakan gelombang near infrared dan model jaringan saraf tiruan. Jurnal Departemen Teknik Mesin dan Biositem IPB. 1:77. 